\title{
Winter wheat variability according to local conditions
}

\author{
Mykola NAZARENKO ${ }^{1,2}$, Irina SOLOHUB ${ }^{3}$, Olexandr IZHBOLDIN ${ }^{3}$
}

Received February 13, 2019; accepted September 12, 2019. Delo je prispelo 13. februarja 2019, sprejeto 12. septembra 2019.

\section{Winter wheat variability according to local conditions}

Abstract: The objectives of our experiments are the description of the phenotypic and genotypic variability by the main agriculture-value traits of the new winter wheat lines according to their interactions with different environmental conditions. Five new winter wheat lines were investigated at field experiment during three years by parameters of grain productivity and quality, uptaking of macro- and microelements and heavy metals from soil under different relief conditions.

Our investigations confirmed statement about more perspective direction for exploiting local sources for winter wheat improvement and closely relation between concentration of nutrient substances in plants, their loss from soil and peculiarities of relief, genotype and limits of adaptation. We developed highadaptive line 213 ('Leana'), which provides us higher than standard grain yield under all conditions. All lines showed higher grain productivity under favorable conditions than control. Variability of traits was higher under south slope conditions (unfavorable conditions) rather than on other (proper conditions). Only line 156 was identified by good protein content and composition under every condition for gliadin and glutenin components. Influence of relief on microelements and heavy metals uptake to the winter wheat plants is not so important as for macroelements and, in consequence, for grain productivity and quality. wheat.
Key words: agrolandscape; growing conditions; winter
Spremenljivost ozimne pšenice glede na lokalne razmere

Izvleček: Namen poskusov je bil opisati fenotipsko in genotipsko spremenljivost glavnih agronomskih lastnosti linij ozimne pšenice glede na njihove interakcije $\mathrm{z}$ različnimi okoljskimi razmerami. Pet novih linij ozimne pšenice je bilo preučevano v poljskem poskusu v treh zaporednih letih glede na parametre pridelka in kakovosti zrnja, privzem makro in mikrohranil ter težkih kovin iz tal v različnih reliefnih razmerah.

Raziskava je potrdila spoznanja o bolj perspektivnih smernicah za izkoriščanje lokalnih danosti za izboljšanje ozimne pšenice in tesno povezanost med koncentracijo hranil v rastlini in njihovo izgubo iz tal, kot tudi posebnosti reliefa in genotipa in omejenosti prilagajanja. Vzgojili so zelo prilagodljivo linijo 213 ('Leana'), ki daje večji pridelek zrnja od standarda v vseh razmerah. Vse linije so imele v ugodnih razmerah večji pridelek zrnja kot kontrola. Spremenljivost lastnosti je bila na neugodnih južnih legah večja kot na drugih, ustreznih razmerah. Samo linija 156 je bila prepoznana po dobri vsebnosti in sestavi proteinov $\mathrm{v}$ vseh razmerah glede na vsebnost gliadina in glutenina. Vpliv reliefa na prevzem mikroelementov in težkih kovin pri ozimni pšenici ni tako pomemben kot za makroelemente in posledično za pridelek ter kakovost zrnja.

Ključne besede: kmetijska pokrajina; rastne razmere; ozimna pšenica

1 Dnipro State Agrarian and Economic University, Department of Plant Breeding and Seeds Production, Ukraine

2 Corresponding author, e-mail: nik_nazarenko@ukr.net

3 Dnipro State Agrarian and Economic University, Department of Plant Production, Ukraine 


\section{INTRODUCTION}

One of the main problem of bread wheat improvement at new century is using of local sources for improvement in breeding programs. Regarding the annual production of about 757 million tons (in 2017) (USDA, 2018), bread wheat (Triticum aestivum L.) occupied the first place as a major cereal crop in the worlds trade. Winter wheat is not only a world's leading cereal crop but also the most important food crop in Ukraine, which has occupied leading position in the national agriculture, taking about $48 \%$ area under cereals and contributing $38 \%$ of the total food grain production (Nazarenko, 2016). As for the quality traits winter wheat is the main stable crop for our country and provides more than $20 \%$ of calories and proteins. Focused on only yield traits we have to understand that any high yield has no sense without proper quality for food and fodder demands (Shewry et al., 2012). During the 19th century, traditional varieties were mainly landraces that were well suitable to their local conditions. But from the beginning of the 20th century, general situation was rapidly changing, the majority of genotypes were out of this process, first of all for regions with specific conditions (Bordes et al., 2008). In the last 60 years plant breeding programs in terms of intensive agriculture led to the total replacement of landraces by modern semi-dwarf and high-yielding varieties, correlating with a decrease in wheat genetic diversity and needs in special requirements for realization their potential, but local sources were not taken into account at this process (Kharytonov et al., 2017; Nazarenko, 2017). Wheat improvement, which bases on the principal of ecological adaptability and taking into account special interactions between environment and genotypes, special abilities for changeability under unfavorable conditions provides us new approaches for formation stable agroecological systems without great losses at productivity (as an example local programs of INRA (France) (Bordes et al., 2011).

All efforts in past research on wheat improvement both at the genotype level and by technology, have been focused on obtaining more highly adaptive forms, not taking into account specific local conditions. Moreover, only a limited set of initial material was actively used. Higher priority was given to geographical areas and only at the end of the 20th century the efforts were focused on agro-ecological districts (Dawson et al., 2011).

Key attention we pay to major groups of agronomic-value traits, grain productivity (and formation of this trait) and grain quality. These traits in interaction with environment actually determine the overall wheat genotypes suitability for farming (Gepts \& Hancock, 2006). Winter wheat yield has the most important and complex character affected directly or indirectly by genome sys- tems present in plant (Rangare et al., 2010) as well as interaction with environment (Tester \& Langridge, 2010; Serpolay et al., 2011). Thus, ecological assessment (part of evaluation process in breeding program for measurements of adaptation for new lines and varieties under difference regional conditions) of new wheat lines with high yield and quality genetic potential under difference condition (local and landscape), it's components (Slafer \& Andrade, 1993) and interaction (Sperling et all, 2001) have become a permanent task in the plant farming and breeding programs (Reif et al., 2005; Tuberosa \& Salvi, 2006).

Regarding the fact of instability in agroecosystems related to types of agroecodistricts and relief type at interaction we investigated lines requirements under different types of slopes. One of the main nature factors for evaluation is a land relief, which is determined by balance of moisture, character of winter wheat growth and development, differences in seasons conditions (Andrusevich et al., 2018).

Grain storage proteins include about $60-80 \%$ of the total protein in wheat grains and metabolic proteins, remaining part consists of the albumins and globulins (15-20\%) (Dai et al., 2015). Grain storage proteins are produced by plants during the effective filling phase of plant development (Shewry et al., 2012; Bonnot et al., 2017; Khalili et al., 2018). Gluten proteins represent major protein fraction of the grain and are responsible for unique properties of the dough. Major determinants of wheat quality are storage proteins. Proteins from wheat flour combined with water formed gluten, which holds gas produced by yeast during baking. Gluten proteins are gliadins and glutenins (Anjum et al., 2007; Katyal et al., 2017). For proper protein composition we need available $\mathrm{N}$ and $\mathrm{S}$ in the soil, which highly influence quality characteristics (Tribo et al., 2003; Chope et al., 2014). There is a strongly negative correlation between grain yield and grain protein (Slafer \& Andrade, 1993; Oury \& Godin, 2007).

The objectives of our experiments are the description of the phenotypic and genotypic (part of dispersion, which determined only by genotype, not by climate or other factors) variability of the main agriculture-value traits of the new winter wheat lines according to their interactions with different environmental conditions. One of the main tasks is how reactions on specific conditions of our region of local breeding lines are different from national officially released varieties. Second purpose is evaluation of agronomic-value traits variability of local sources and local possibilities for successful creation new material for winter wheat improvement under special conditions of region, possibilities of new genotypes in 
formation of ecological adaptation (Nazarenko \& Bezus, 2018).

\section{MATERIALS AND METHODS}

Experiments were conducted at the experimental fields of Dnipropetrovsk State Agrarian and Economic University. The field's geographic coordinates are: $48^{\circ} 30^{\prime} \mathrm{N}$ lat. and $35^{\circ} 15^{\prime} \mathrm{E}$ long. The experimental fields are lied down on 245 meters above the sea level. Weather conditions for hydrothermal indicators in the years of research $(2015$ - 2017) varied, which made possible to obtain objective results, but in general, they were typical. Air temperature during winter wheat growing season (September - July) is $8.5^{\circ} \mathrm{C}$, the average rainfall is $511 \mathrm{~mm}$ for the location of the research fields (air temperature during winter wheat growing season 2015 (September - July) was $9.8^{\circ} \mathrm{C}$, the average rainfall is about $622.8 \mathrm{~mm}$; air temperature in season 2016 was $10.4{ }^{\circ} \mathrm{C}$, the average rainfall is about $512.0 \mathrm{~mm}$; air temperature in season 2017 was $9.2^{\circ} \mathrm{C}$, the average rainfall is about $533.8 \mathrm{~mm}$.

The field station of Dnipro State Agrarian and Economic University has been used for many years (start from $60^{\text {th }}$ years of XX century) as a field for intensive agricultural farming and researches (Kharytonov et.al., 2017). It is located far away from the city Dnipro (about $28 \mathrm{~km}$ ) which is enough to avoid industrial or town air pollution effects. The research fields occupy an area of 60 hectares and are situated acrossed three types of landscapes. One of them is of $30 \mathrm{~m}$ deep valley with a slope of $>7^{\circ}$, the other two have the slopes up to $3^{\circ}$. Comparison of the received information in aspects of the crop yield and quality due to the landscape peculiarities gives us the arguments to classify the agricultural resource potential for different type of agrolandscapes. Investigation was performed on flat (full-height normal soil), on the northern exposition slope (low eroded soil), on the southern exposure slope (middle level of erosion). Special attention was paid to the differences on several agronomical-value traits (grain yield, protein and main protein components content in grains, assimilation of main macro- and microelements).

Winter wheat seeds were obtained from department of breeding and seedfarming of Dnipro State Agrarian and Economic University (line number 130 ('Giant', seeds of variety 'Kalinova' were subjected by gamma-rays, 100 Gy), 156 ('Leroy', seeds of 'Kolos Mironovschiny' was treated by nitrosomethilurea $0.0125 \%$ at water solution during 18 hours), 157 ('Sonechko', 100 Gy), 211 ('Deada', 'Kolos Mironovschiny', nitrosomethilurea 0.0125\%) 213 ('Leana', 'Favoritka', nitrosomethilurea 0.0125\%) (Naza- renko et al., 2018). The recommended intensive agronomic practice was followed (N $180 \mathrm{~kg} \mathrm{ha}^{-1}, \mathrm{P} 60 \mathrm{~kg} \mathrm{ha}^{-1}$, $\mathrm{K} 40 \mathrm{~kg} \mathrm{ha}^{-1}$ ). Evaluation of total grain yield of five lines per plot was calculated from 2015 to 2017 years. The control was national standard variety Podolyanka. The trial was set up at a randomized block design method with three replications and with a plot size of $10 \mathrm{~m}^{2}$ in 3 replications (Bhutta et al., 2005). Coefficients of nutrient elements utilization were calculated as the ratio of element content in yield to the content of element in the soil and from fertilizers (in percent). Agrochemical analysis of soils for content of nutrient elements was provided too $\left(\mathrm{N}-\mathrm{NO}_{3}, \mathrm{mg} \mathrm{kg}^{-1} 18.7-32.8, \mathrm{P}_{2} \mathrm{O}_{5} 14.8-27.1, \mathrm{~K}_{2} \mathrm{O} 134\right.$ $-235)$.

The nitrogen and phosphorus concentration in plant samples was estimated using Kjeldahl method. Total P concentrations of the applied residues were determined by sulfuric acid digestion (Thomas et al., 1967). Potassium was determined with flame photometry. Trace elements were determined with method of atomic absorption spectrophotometry. The protein content and contents of gliadin and glutenin were identified on device CNS Model Flash EA 1112 (for protein content) and RPHPLS (for gliadins and glutenins).

Mathematical processing of the results was performed by the method of analysis of variance, the variability of the mean difference was evaluated by Student's t-test, factor analyses were conducted by module ANOVA. In all cases standard tools of the program Statistica 8.0 were used.

\section{RESULTS AND DISCUSSION}

Winter wheat lines (Tables 1 and 2) are sensitive to cultivation under different conditions with statistical certainty, but not within as wide a range of varieties and with some differences for one line. These differences in terms of growing conditions are expressed in grain productivity and the ability to use basic nutrients from the soil. Regarding the grain productivity, Table 1 shows that higher yields are typical for the lines on the slope of the northern exposure, especially for lines 157,213 , however, the remaining lines also exceeded the standard in terms of yielding capacity. In all cases, the new lines needed larger doses of fertilizer to form the yield bigger than the standard. All of the new lines belong to intensive winter wheat type (Nazarenko et al., 2018). Efficiency in utilization of main nutrient elements are depended on following factors, such as genotype $\left(\mathrm{F}=14.75 ; \mathrm{F}_{\text {critical }}=3.16\right.$; $\mathrm{p}$-level $0.01)$, type of landscape $\left(\mathrm{F}=8.70 ; \mathrm{F}_{\text {critical }}=3.34 ; \mathrm{p}\right.$-level $0.01)$ and quantity of mineral nutrients $\left(\mathrm{F}=4.16 ; \mathrm{F}_{\text {critical }}=\right.$ 4.01; p-level 0.02) available for plants. 
Table 1: Yield and utilization of main nutrient macroelements by winter wheat plants

\begin{tabular}{|c|c|c|c|c|c|c|c|}
\hline \multirow[b]{2}{*}{ Variety, line } & \multirow[b]{2}{*}{ Yield, $\mathrm{t} \mathrm{ha}^{-1}$} & \multicolumn{3}{|c|}{ Uptake from soil $\mathrm{kg} \mathrm{ha}^{-1}$} & \multicolumn{3}{|c|}{ For 1 ton of grain, $\mathrm{kg}$} \\
\hline & & $\mathrm{N}$ & $\mathrm{P}$ & K & $\mathrm{N}$ & $\mathrm{P}$ & K \\
\hline \multicolumn{8}{|l|}{ Flat } \\
\hline Podolyanka & 8.8 & 273.7 & 83.6 & 213.0 & 31.1 & 9.5 & 24.2 \\
\hline 130 & $10.5^{\star}$ & 342.2 & 111.6 & 247.5 & 32.5 & 10.6 & 23.5 \\
\hline 156 & $9.1^{*}$ & 299.5 & 98.6 & 220.9 & 32.8 & 10.8 & 24.2 \\
\hline 157 & $11.2^{*}$ & 380.4 & 103.2 & 272.6 & 33.9 & 9.2 & 24.3 \\
\hline 211 & $10.2^{*}$ & 352.2 & 98.5 & 246.6 & 34.7 & 9.7 & 24.3 \\
\hline 213 & $11.5^{\star}$ & 402.6 & 110.1 & 281.0 & 35.1 & 9.6 & 24.5 \\
\hline Average & 10.2 & 341.8 & 100.9 & 246.9 & 33.4 & 9.9 & 24.2 \\
\hline \multicolumn{8}{|c|}{ Slope of noth exposition } \\
\hline Podolyanka & 8.4 & 261.2 & 79.8 & 200.8 & 31.1 & 9.5 & 23.9 \\
\hline 130 & $10.4^{\star}$ & 317.2 & 103.0 & 249.6 & 30.5 & 9.9 & 24.0 \\
\hline 156 & $9.8^{* \wedge}$ & 301.8 & 97.0 & 235.2 & 30.8 & 9.9 & 24.0 \\
\hline 157 & $11.9^{\star \wedge}$ & 389.1 & 103.5 & 285.6 & 32.7 & 8.7 & 24.0 \\
\hline 211 & $11.5^{\star \wedge}$ & 389.9 & 108.1 & 273.7 & 33.9 & 9.4 & 23.8 \\
\hline 213 & $11.7^{\star}$ & 402.5 & 107.6 & 279.6 & 34.4 & 9.2 & 23.9 \\
\hline Average & 10.6 & 343.6 & 99.8 & 254.1 & 32.2 & 9.4 & 23.9 \\
\hline \multicolumn{8}{|c|}{ Slope of south exposition } \\
\hline Podolyanka & $7.2^{\wedge}$ & 201.6 & 64.8 & 146.2 & 28.0 & 9.0 & 20.3 \\
\hline 130 & $8.1^{\wedge}$ & 251.1 & 76.1 & 190.4 & 31.0 & 9.4 & 23.5 \\
\hline 156 & $8.3^{\wedge}$ & 257.3 & 80.5 & 200.9 & 31.0 & 9.7 & 24.2 \\
\hline 157 & $7.2^{\wedge}$ & 234.0 & 64.1 & 175.0 & 32.5 & 8.9 & 24.3 \\
\hline 211 & $6.9^{\wedge}$ & 224.3 & 60.7 & 167.7 & 32.5 & 8.8 & 24.3 \\
\hline 213 & $8.5^{\star \wedge}$ & 255.9 & 72.3 & 173.4 & 30.1 & 8.5 & 20.4 \\
\hline Average & 7.7 & 237.4 & 69.8 & 175.6 & 30.9 & 9.1 & 22.8 \\
\hline
\end{tabular}

* - is significantly from control on $5 \%$ level, $\wedge$ - is significantly from flat on $5 \%$ level

After analyzing the special needs of the lines (Table 1) in nutrients used by winter wheat plants for growth and development and the number of elements required to obtain 1 ton of grain, it was found that the need for basic nutrients primarily depends on the genetically determined characteristics of these lines in the formation of the grain crop yield (Lazrak et al., 2010).

Nitrogen utilization by winter wheat plants on flat sites were from 273.7 (national standard 'Podolyanka') to $402.6 \mathrm{~kg} \mathrm{ha}^{-1}$ (line 213), phosphorus 83.6 (national standard 'Podolyanka') - 111.6 (line 130) $\mathrm{kg} \mathrm{ha}^{-1}$, potassium 213.0 (national standard 'Podolyanka') - $281.0 \mathrm{~kg} \mathrm{ha}^{-1}$ (line 130) during three years. We can see that difference in demands for different elements depend on winter wheat lines peculiarities and more adaptable genotypes have fewer demands for mineral sources (Ladoni et al., 2017). Some of the lines needed more nitrogen (line 213), but others (line 130) needed more phosphorus to form the grain. From 31.1 (variety Podolyanka) to 35.1 kilograms of nitrogen is required to obtain 1 ton of winter wheat, 9.5 (variety Podolyanka) - 10.8 (line 156) kg of phosphorus and from 23.5 (line 130) for $24.5 \mathrm{~kg}$ (line 213) of potassium.

From the above data, we could find out that the most productive line 213 , in general, needs more nitrogen and phosphorus than other genotypes. The same line needs only more nitrogen than other lines for the formation of 1 ton of grain, phosphorus is more significant in the context of the same indicator for the line 156. Potassium is not so important and is required at about the same level for all lines and variety Podolyanka. From the results of the protein components study, winter wheat lines with large requirements for phosphorus provide good grain quality (Bonnot et al., 2017).

In more favorable conditions of a northern exposure, differences in yielding capacity are not so signifi- 
Table 2: Coefficient of nutrient elements utilization from soil on different types of relief, \%

\begin{tabular}{|c|c|c|c|c|c|c|c|c|c|}
\hline \multirow[b]{2}{*}{ Variety, line } & \multicolumn{3}{|l|}{ Flat } & \multicolumn{3}{|c|}{ Slope of north exposition } & \multicolumn{3}{|c|}{ Slope of south exposition } \\
\hline & $\mathrm{N}$ & $\mathrm{P}$ & $\mathrm{K}$ & $\mathrm{N}$ & $\mathrm{P}$ & $\mathrm{K}$ & $\mathrm{N}$ & $\mathrm{P}$ & $\mathrm{K}$ \\
\hline Podolyanka & 62.9 & 57.0 & 17.0 & 69.1 & 89.5 & 20.3 & 74.7 & 87.9 & 23.0 \\
\hline 130 & 53.3 & 61.6 & 15.7 & 59.1 & 86.8 & 17.5 & 60.9 & 85.4 & 18.0 \\
\hline 156 & 59.0 & 60.7 & 15.7 & 60.0 & 89.0 & 17.5 & 60.5 & 85.1 & 18.6 \\
\hline 157 & 60.6 & 45.1 & 13.9 & 65.2 & 76.6 & 17.0 & 74.1 & 80.4 & 20.0 \\
\hline 211 & 63.0 & 50.3 & 16.5 & 64.3 & 69.0 & 17.5 & 71.1 & 72.3 & 19.8 \\
\hline 213 & 64.8 & 57.1 & 15.8 & 69.7 & 83.9 & 17.3 & 78.4 & 88.4 & 23.9 \\
\hline Average & 59.8 & 54.9 & 15.8 & 63.5 & 82.2 & 18.0 & 68.3 & 82.2 & 19,9 \\
\hline
\end{tabular}

cant between the lines comparing to the upland soils. For the two lines - 130 and 213 , yielding capacity remained at about the same level as for the upland soils, for the other three lines yielding capacity is higher than on the upland soils, but in any case, all of the lines exceed the control for yielding capacity. It is required within 216.2 - $402.5 \mathrm{~kg} \mathrm{ha}^{-1}$ of nitrogen, phosphorus 79.8 - $108.1 \mathrm{~kg}$ $\mathrm{ha}^{-1}$, potassium $200.8-285.6 \mathrm{~kg} \mathrm{ha}^{-1}$ from the soil for crop formation.

The reaction of individual genotypes to the growing conditions shows the same situation as for the previous conditions, only line 213 differs by specific high phosphorus needs. The similar situation was observed on features of the use of mineral substances on the formation of 1 ton of grain. Line 213 has shown the ability to use less nutrients for crop formation in contrast to other lines, which allows it to provide higher yields in adverse conditions.

According to the results of the grain yield and the use of macronutrients from the soil, all lines can be divided into two groups. The first group (line 213) provides a higher yield than the standard in all cases, which sharply distinguishes it from the rest of the lines (and varieties in previous studies). The yields in the second group (all other lines) are inferior to standard in adverse condi- tions, because the standard belongs to the semi-intensive varieties and has an advantage due to low demands for mineral nutrition in adverse conditions compared to intensive ones. Cases like the line 213 (when intensive variety exceeds the variety of standard in adverse conditions) have not been observed and this indicates the possibilities of obtaining a highly adaptive intensive genotype in the framework of the intensive varieties that had previously relied possible only theoretically (Nazarenko \& Lykholat, 2018).

In accordance with the data on the use of macronutrients from the soil, it can be concluded that there is mutual influence of the type of agricultural landscape (in the sense of terrain features) and genotype on this parameter. It can be concluded that plants use nutrients more rationally in the harsher conditions of the southern exposure than in other variants. It shows wide adaptability of winter wheat plants in different agro-ecological conditions. In the case of the phosphorus use by plants, the differences in the results on the slopes of the northern and southern exposure are not so significant and reliable on average. The consumption of this macronutrient is more dependent on the special needs of individual lines.

The total intake of 6 elements is summarized in tables 3 and 4 . Thus, according to the previous studies, the

Table 3: Intake of microelements and heavy metals with winter wheat grains and straw under different agrolandscape conditions $\mathrm{mg} \mathrm{kg}^{-1}$

\begin{tabular}{|c|c|c|c|c|c|c|}
\hline Relief element & $\mathrm{Zn}$ & $\mathrm{Mn}$ & $\mathrm{Cu}$ & $\mathrm{Pb}$ & $\mathrm{Ni}$ & $\mathrm{Fe}$ \\
\hline \multicolumn{7}{|l|}{ Grain } \\
\hline Flat & 20.1 & 19.2 & 2.8 & 1.9 & 2.9 & 38.9 \\
\hline Slope of north exposition & 18.9 & 26.9 & 5.0 & 2.0 & 1.7 & 39.4 \\
\hline Slope of south exposition & 22.7 & 24.1 & 4.3 & 2.0 & 1.9 & 30.1 \\
\hline \multicolumn{7}{|l|}{ Straw } \\
\hline Flat interfluve & 4.7 & 16.9 & 3.1 & 3.1 & 2.9 & 75.9 \\
\hline Slope of north exposition & 2.9 & 14.5 & 2.5 & 2.5 & 1.9 & 26.7 \\
\hline Slope of south exposition & 2.1 & 9.2 & 2.1 & 2.7 & 1.2 & 24.7 \\
\hline
\end{tabular}


Table 4: General uptake of microelements and heavy metals with yield under different relief conditions, $\mathrm{g} \mathrm{ha}^{-1}$

\begin{tabular}{|c|c|c|c|c|c|c|}
\hline Relief element & $\mathrm{Fe}$ & $\mathrm{Zn}$ & $\mathrm{Mn}$ & $\mathrm{Cu}$ & $\mathrm{Ni}$ & $\mathrm{Pb}$ \\
\hline Flat interfluve & 5723.0 & 1219.2 & 1437.6 & 354.2 & 312.6 & 212.3 \\
\hline Slope of north exposition & 3211.1 & 1213.4 & 2348.1 & 445.2 & 211.3 & 279.2 \\
\hline Slope of south exposition & 1824.2 & 1111.1 & 1116.5 & 243.9 & 163.2 & 211.6 \\
\hline Average & 2517.7 & 1181.2 & 1647.7 & 347.8 & 229.0 & 234.4 \\
\hline $\mathrm{Cv}, \%$ & 980.7 & 60.8 & 622.5 & 100.8 & 76.3 & 38.8 \\
\hline
\end{tabular}

wheat grain contains more essential microelements than straw, while the situation with undesirable elements is the opposite. Thus, lead and nickel could be found more in the straw. This is not unusual because it is determined by the biological laws of plant development. This is one of the natural mechanisms for avoiding the high concentration of adverse elements in the reproductive organs of the plant and ensure the provision of the necessary substances. No statistically significant relations between concentrations of trace elements, heavy metals and relief conditions were detected. Data on the concentration of these elements depending on the growing conditions are inconsistent and there is no statistically significant difference (Table 3, 4) (type of landscape $\left(\mathrm{F}=1.17 ; \mathrm{F}_{\text {critical }}=\right.$ 2.91; p-level 0.04)) as in previous studies (Nazarenko \& Lykholat, 2018).

On the other hand, a decrease in the content of some microelements $(\mathrm{Zn}, \mathrm{Mn}, \mathrm{Fe})$ in straw under any terrain conditions should be noted (which is fully consistent with previous studies in this area). The intake of microelements from soil to wheat grain varied for iron from 1.824.2 to $5.723 .0 \mathrm{~g} \mathrm{ha}^{-1}$, zinc 1.111 .1 - 1.219.2 $\mathrm{g} \mathrm{ha}^{-1}$, manganese 1.116 .5 - 2.348.1 $\mathrm{g} \mathrm{ha}^{-1}$, copper 243.9 $445.2 \mathrm{~g} \mathrm{ha}^{-1}$, lead 211.6 - $279.2 \mathrm{~g} \mathrm{ha}^{-1}$, nickel 163.2 $312.6 \mathrm{~g} \mathrm{ha}^{-1}$. The content of microelements in grain from the southern exposure slope was significantly lower than that obtained from the upland soils and northern exposure slope.

It is impossible to determine any differences in this situation from the data of cultivation in different conditions, unlike previous studies (Kharitonov et al., 2017), where such a relation was observed. That is why, it can be concluded that the dependence of this feature primarily bases on the genotype of this line, and not on the growing conditions (Han et al., 2017).

Higher protein content (statistically) has been recognized in winter wheat grains of two lines 157 and 213 ('Leana') (Table 5). We cannot identify any differences between growing conditions and we have to conclude that it's depended only on genotype of winter wheat line, not from the growth conditions in our experiment like as in previous investigations (Snapp \& Kravchenko, 2015). Both lines (157 and 213) have a good composition of protein under any conditions (and good quality of protein), but not superior.

Lines 130 and 156 were determined as superior in gliadin and glutenin content in all terrain conditions. Similar varieties in this quality have been identified as holders of high baking characteristics in previous studies (Bordes et al., 2008; Bonnot et al., 2017), which gives grounds for the highlighting of these genotypes.

Thus, in general, lines 157 and 213 (the latter also holds for the high level of grain productivity and stability

Table 5: Protein content in winter wheat grains depending on line and agrolanscape, $\%$

\begin{tabular}{|c|c|c|c|c|c|c|c|c|c|}
\hline \multirow[b]{2}{*}{ Variety, line } & \multicolumn{3}{|l|}{ Flat } & \multicolumn{3}{|c|}{ Slope of north exposition } & \multicolumn{3}{|c|}{ Slope of south exposition } \\
\hline & gliadin & glutenin & protein & gliadin & glutenin & protein & gliadin & glutenin & protein \\
\hline Podolyanka & 13.5 & 0.024 & 0.61 & 13.6 & 0.020 & 0.62 & 13.5 & 0.021 & 0.63 \\
\hline 130 & 13.3 & 0.031 & 0.72 & 13.5 & 0.033 & 0.73 & 13.3 & 0.033 & 0.75 \\
\hline 156 & 13.6 & 0.033 & 0.74 & 13.7 & 0.034 & 0.76 & 13.5 & 0.032 & 0.75 \\
\hline 157 & $14.3^{*}$ & 0.025 & 0.65 & $14.5^{\star}$ & 0.023 & 0.64 & $14.1^{\star}$ & 0.024 & 0.62 \\
\hline 211 & 13.5 & 0.024 & 0.66 & 13.7 & 0.024 & 0.65 & 13.4 & 0.023 & 0.66 \\
\hline 213 & $13.9^{*}$ & 0.023 & 0.67 & $14.1^{\star}$ & 0.024 & 0.63 & $14.0^{\star}$ & 0.024 & 0.65 \\
\hline Average & 13.7 & 0.027 & 0.68 & 13.9 & 0.026 & 0.67 & 13.6 & 0.026 & 0.68 \\
\hline $\mathrm{Cv}, \%$ & 2.6 & 15.9 & 7.1 & 2.6 & 21.8 & 8.7 & 1.9 & 19.2 & 8.7 \\
\hline
\end{tabular}

*- is significantly on $5 \%$ level. 
of this feature under all conditions; a high level of adaptability) can be highlighted in the complex on the content and quality of protein. Only line 156 showed the quality of protein under all conditions.

Thus, like as in previous studies (Bordes et al., 2011) grain quality is depended on genotype only, not from agrolandscape types. This statement is appropriate for new lines and intensive varieties (Nazarenko \& Lykholat, 2018), but not for older varieties (Kharitonov et al., 2017). Besides the quality, grain productivity is depended on both genotype and growth conditions, like as at previous investigations (Serpolay et al., 2011; Milev et al., 2014). Differences in relief type (not only climate conditions for region (Bhutta et al., 2005; Tsenov et al., 2015; Hatfield \& Dold, 2018) are new local factor for varieties phenotypic variability, which has a great influence on general grain productivity (Gepts \& Hancock, 2006; Kharitonov et al., 2017). Unlike varieties in previous studies (Kharitonov et al., 2017; Nazarenko \& Lykholat, 2018), one of the new lines (213) has shown a consistently high (higher than control) yield in any relief conditions.

\section{CONCLUSIONS}

Field experiments on yield and grain quality of main cereal crops are usually limited to a one type (flat) of agrolandscape, one or two points in geographical zone and are measured on number of officially released varieties (well-known, not new lines). These ecological surveys are conducted without any record on genotype special demands in nutrition sources and ecological requirements to realize potential yield and grain quality traits. The wide phenotypic variability for the most of the agricultural-value traits investigated is indicative of the large diversity of the genotypes and genotype-environment interactions, mutual influences of landscape, local climate conditions in terms of agroecological district and genotype peculiarities.

Finally, our investigations confirmed statement about more perspective directions for exploiting local sources for winter wheat improvement and closely relation between concentration of nutrient substances in plants, their loss from soil and peculiarities of relief, genotype and limits of adaptation. Generally, north exposition gives winter wheat more preferable conditions for growth and development, but one high-adaptive line 213 ('Leana') was determined, which provided higher than standard grain yield under all conditions, include unfavorable. Protein content and quality depends on genotype, not on relief conditions. Yields of new lines obtained base on local sources as a result of selection under local conditions, and are less depends on growth conditions (type of relief) than officially released varieties.

\section{REFERENCES}

Andrusevich, K.V., Nazarenko, M.M., Lykholat, T.Yu., \& Grigoryuk, I.P. (2018). Effect of traditional agriculture technology on communities of soil invertebrates. Ukrainian journal of Ecology, 8(1), 33-40. https://doi.org/10.15421/2018_184

Anjum, F.M., Khan, M.R., Din, A., Saeed, M., Pasha, I., \& Arshad, M.U. (2007). Wheat gluten: high molecular weight glutenin subunits - structure, genetics, and relation to dough elasticity. Journal of Food Science, 72(3), 56-63. https://doi.org/10.1111/j.1750-3841.2007.00292.x

Bhutta, W.M., Akhtar, J., Anwar-ul-Haq, M., \& Ibrahim, M. (2005). Cause and effect relations of yield components in spring wheat (Triticum aestivum L.) under normal conditions. Caderno de Pesquisa Serie Biologia, Santa Cruz do Sul, 17(1), 7-12.

Bordes, J., Branlard, G., Oury, F.X., Charmet, \& Balfourier, G. F. (2008). Agronomic characteristics, grain quality and flour rheology of 372 bread wheats in a worldwide core collection. Journal of Cereal Science, 48(3), 569-579. https://doi. org/10.1016/j.jcs.2008.05.005

Bordes, J., Ravel C., Le Gouis J., Lapierre A., Charmet G., \& Balfourier F. (2011). Use of a global wheat core collection for association analysis of flour and dough quality traits. Journal of Cereal Science, 54, 137-134. https://doi.org/10.1016/j. jcs.2011.03.004

Bonnot, T., Bance, E., Alvarez, D., Davanture, M., Boudet, J., Pailloux, M., Zivy, M., Ravel, C., \& Martre, P. (2017). Grain subproteome responses to nitrogen and sulfur supply in diploid wheat Triticum monococcum ssp. Monococcum. The Plant Journal, 91(5), 894-910. https://doi.org/10.1111/ tpj. 13615

Chope, G.A., Wan, Y., Penson, S.P., Bhandari, D.G., Powers, S.J., Shewry, P.R., \& Hawkesford, M.J. (2014). Effects of genotype, season, and nitrogen nutrition on gene expression and protein accumulation in wheat grain. Journal of Agricultural Food Chemistry, 62, 4399-4407. https://doi.org/10.1021/ jf500625c

Dai, Z., Plessis, A., \& Vincent, J. (2015). Transcriptional and metabolic alternations rebalance wheat grain storage protein accumulation under variable nitrogen and sulfur supply. Plant Journal, 83, 326-343. https://doi.org/10.1111/ tpj.12881

Dawson, J. C., Rivire, P., \& Berthellot, J. F. (2011). Collaborative Plant Breeding for Organic Agricultural Systems in Developed Countries. Sustainability, 3, 1206-1223. https://doi. org/10.3390/su3081206

Han, Z., Walter, M.T., \& Drinkwater, L.E. (2017) N2O emissions from grain cropping systems: a meta-analysis of the impacts of fertilizer-based and ecologically-based nutrient management strategies. Nutrient Cycling in Agroecosystems, 107 335-355.

Hatfield, J. L., \& Dold, C. (2018). Agroclimatology and Wheat 
Production: Coping with Climate Change. Frontier Plant Sciences, 9, 1-5. https://doi.org/10.3389/fpls.2018.00224

Khalili, M., Naghavi, M., \& Yousefzadeh, S. (2018). Protein pattern analysis in tolerant and susceptible wheat cultivars under salinity stress conditions. Acta agriculturae Slovenica, 111(3), 545-558. https://doi.org/10.14720/ aas.2018.111.3.03

Gepts, P., \& Hancock, J. (2006). The future of plant breeding. Crop Science, 46, 1630-1634. https://doi.org/10.2135/cropsci2005-12-0497op

Katyal, M., Virdi, S.V., Kaur, A., Singh, N., Kaur, S., Ahlawat, A.K., \& Singh, A.M. (2016). Diversity in quality traits amongst Indian wheat varieties I: Flour and protein characteristics. Food Chemistry, 194, 337-344. https://doi org/10.1016/j.foodchem.2015.07.125

Kharytonov, M.M., Pashova, V. T., Mitsik, O.O., Nazarenko, M.M., \& Bagorka, M.O. (2017). Estimation of winter wheat varieties suitability for difference growth of landscape conditions. Annals of the Faculty of Engineering Hunedoara, 15(4), 187-191.

Ladoni, M., Basir, A., Robertson, P.G., \& Kravchenko, A.N. (2016) Scaling-up: cover crops differentially influence soil carbon in agricultural fields with diverse topography. Agriculture Ecosystems \& Environment, 225, 93-103. https://doi. org/10.1016/j.agee.2016.03.021

Lazrak E.G, Mari J.F, \& Benoit M. (2010) Landscape regularity modeling for environmental challenges in agriculture. Landscape Ecology, 25, 1-15. https://doi.org/10.1007/ s10980-009-9399-8

Mba, C., Guimaraes, E.P., \& Ghosh, K. (2012). Re-orienting crop improvement for the changing climatic conditions of the 21st century. Agriculture \& Food Security, 7, 1-17. https://doi.org/10.1186/2048-7010-1-7

Milev, G., Nankov, N. , Iliev, I., Ivanova A., \& Nankova, M. (2014). Growing Wheat (Trititcum aestivum L.) by the Methods of Organic Agriculture Under the Conditions of Dobrudzha Region, Bulgaria. Turkish journal of agricultural and natural sciences, 1, 849-857.

Nazarenko, M. (2016). Parameters of winter wheat growing and development after mutagen action. Bulletin of Transilvania University of Brasov - series II - Forestry, Wood Industry, Agricultural, Food Engineering, 9(2), 109-116.

Nazarenko, N.N. (2017). Specific Features in the Negative Consequences of a Mutagenic Action. Russian Journal of Genetics: Applied Research, 7(2), 195-196. https://doi. org/10.1134/S2079059717020083

Nazarenko M., \& Lykholat, Y. (2018). Influence of relief conditions on plant growth and development. Dnipro university bulletin. Geology. Geography, 26(1), 143-149. https://doi. org/10.15421/111815

Nazarenko, M., Lykholat Y., Grigoryuk I., \& Khromykh N. (2018). Optimal doses and concentrations of mutagens for winter wheat breeding purposes. Part I. Grain productivity. Journal of Central European Agriculture, 19(1), 194-205. https://doi.org/10.5513/JCEA01/19.1.2037

Nazarenko, M., \& Bezus R. (2018). Interactions between agrolandscape and winter wheat agronomical-value traits. Bul- letin of Transilvania University of Brasov - series II - Forestry, Wood Industry, Agricultural, Food Engineering, 11(60), 141150.

Oury, F. X., \& Godin, C. (2007). Yield and grain protein concentration in bread wheat: how to use the negative relationship between the two characters to identify favourable genotypes? Euphytica, 157(1-2), 45-57. https://doi.org/10.1007/ s10681-007-9395-5

Rangare, N.R., Krupakar, A., Kumar, A., \& Singh, S. (2010). Character association and component analysis in wheat (Triticum aestivum L.). Electronic Journal of Plant Breeding, 1,231-238.

Reif, J.C., Zhang, P., Dreisigacker, S., \& Warburton, M.L. (2005). Wheat genetic diversity trends during domestication and breeding. Theoretical and Applied Genetics, 110, 859-864. https://doi.org/10.1007/s00122-004-1881-8

Serpolay, E., Dawson, J.C., Chable, V., Lammerts Van Bueren, E.,Osman, A., Pino, S., Silveri, D., \& Goldringer, I. (2011). Phenotypic responses of wheat landraces, varietal associations and modern varieties when assessed in contrasting organic farming conditions in Western Europe. Organic Agriculture, 3, 12-18.

Shewry, P.R., Mitchell, R.A.C., \& Tosi, P. (2012). An integrated study of grain development of wheat (cv. Hereward). Journal of Cereal Science, 56, 21-30. https://doi.org/10.1016/j. jcs.2011.11.007

Slafer, G.A., \& Andrade, F.H. (1993). Physiological attributes related to the generation of grain yield in bread wheat cultivars released at different eras. Field Crops Research, 31, 351367. https://doi.org/10.1016/0378-4290(93)90073-V

Snapp, S.S., \& Kravchenko, A. (2015) Cover crop and tillage systems effect on soil $\mathrm{CO} 2$ and $\mathrm{N} 2 \mathrm{O}$ fluxes in contrasting topographic positions. Soil and Tillage Research, 154, 64-74. https://doi.org/10.1016/j.still.2015.06.015

Tsenov, N., Atanasova, D., Stoeva, I. \& Tsenova, E. (2015). Effects of drought on grain productivity and quality in winter bread wheat. Bulgarian Journal Agricultural. Sciences, 21, 592-598.

Tester, M., \& Langridge, P. (2010). Breeding technologies to increase crop production in a changing world. Science, 327, 818-822. https://doi.org/10.1126/science.1183700

Thomas, R.L.; Sheard, R.W., \& Mayer, J.R. (1967). Comparison of conventional and automated procedures for nitrogen, phosphorus and potassium analysis of plant material using a single digestion. Agronomy Journal, 59, 240-243. https:// doi.org/10.2134/agronj1967.00021962005900030010x

Tribo, E., Martre, P., \& Tribo-Blondel, A.M. (2003). Environmentally induced changes in protein composition in developing grains of wheat are related to changes in total protein content. Journal of Experimental Botany, 54, 1731-1742. https://doi.org/10.1093/jxb/erg183

Tuberosa, R., \& Salvi, S. (2006). Genomics-based approaches to improve drought tolerance of crops. Trends in Plant Science, 11, 405-412. https://doi.org/10.1016/j.tplants.2006.06.003

USDA. (2018) World Agricultural Supply and Demand Estimates. Retrieved from https://www.usda.gov/oce/commodity/wasde/latest.pdf. 